\title{
UTERINE CHORIOCARCINOMA - A CASE REPORT
}

\author{
VANDA PARADŽIK PAŠALIĆ, JOŠKO LEŠIN, \\ VIŠNJA MATKOVIĆ and SUZANA LIDE ŠKALEC
}

Department of Gynecological Oncology, University Hospital Centre Zagreb, Zagreb, Croatia

\begin{abstract}
Summary
Choriocarcinoma is one of the histological types of entities called gestational trophoblastic neoplasia (GTN) that refers to a rare group of malignancies that are formed by abnormal proliferation of trophoblastic tissue. Choriocarcinoma is the most aggressive GTN histological type and is characterized by early vascular invasion and disseminated disease. The clinical presentation depends on the spread of the disease and the location of the seedlings. In this paper we present the case of a 32-year-old patient sent to our Department for a specific oncological treatment of uterine choriocarcinoma diagnosed in an external institution. The disease is according to FIGO and WHO scale classified as III stage, low risk and chemotherapy with methotrexate and folic acid is indicated. The chemotherapy achieved negativity of the initially elevated tumor marker human chorionic gonadotropin (hCG) and full regression of lesions described in computerized tomography (CT).
\end{abstract}

KEYWORDS: gestational trophoblastic neoplasia, choriocarcinoma, FIGO and WHO Classification, hCG, methotrexate

\section{INTRODUCTION}

Choriocarcinoma is one of the histological types of entities called gestational trophoblastic neoplasia (GTN), that refers to a rare group of malignancies that are formed by abnormal proliferation of trophoblastic tissue, which can be preceded by either a hydatidiform mole or nonmolar pregnancy. GTN besides choriocarcinoma also involes histological types: invasive mole (IM), placental site trophoblastic tumor (PSTT), and epithelioid trophoblastic tumor (ETT). IM and choriocarcinoma are characterized by high values of human chorionic gonadotropin (hCG) while PSTT and ETT are characterized by low hCG values (1). At a time prior to the development of effective chemotherapy for GTN, most patients with disease limited to uterus were cured with hysterectomy while the metastatic disease was mostly fatal (2). Nowa-

Corresponding author: Vanda Paradžik Pašalić, Department of Gynecological Oncology, University Hospital Centre Zagreb, Petrova 13, 10000 Zagreb, Croatia. e-mail: vparadzikpasalic@gmail.com days, in the development of high sensitivity assays for hCG determination and treatment with high-efficiency chemotherapy, most patients can be cured as well as preserve reproductive function (3). Almost $50 \%$ of GTN is derived from molar pregnancy, $25 \%$ from spontaneous abortion or ectopic (tubular) pregnancy and 25\% from terminal or premature pregnancy. The ultimate cause of gestational throphoblastic disease is claimed to be genetic in origin. No enviromental etiological factor has been implicated up to now apart from deficient vitamin A precursor carotene in the diet (4). Choriocarcinoma is the most aggressive GTN histological type and is characterized by early vascular invasion and disseminated disease. The clinical presentation depends on the spread of the disease and the location of the seedlings.

\section{PATIENT REPORT}

In May 2018 a 32-year-old patient was referred to the Department of Gynecological Oncology, University Hospital Centre Zagreb for a spe- 
cific oncological treatment of a pathohistologically verified uterine choriocarcinoma. Previously in the other institution uterine vacuum aspiration was done due to the suspected molar hydatidose in 7th week of amenorrhea.

The pathohistological findings were: according to histologic and immunohistochemical analysis (Ki-67 in atypical trophoblast cells, primarily cytotrophoblasts, about 90\%, CK 8/18 intensively positive, alpha-inhibitory only focal positive, p63 negative) findings in this material correspond to neoplasms of trophoblast, choriocarcinoma.

Gynecological ultrasound finding: in uterine cavity conglomerate about $3 \mathrm{~cm}, \mathrm{CD}$ highly vascularization. Normal ovaries. No ascites. The hCG value before uterine vacum aspiration was 45,627 and after aspiration 19,246. In our Department further diagnostic processing was done:

Brain CT: no signs of acute ischemia, intracranial hemorrhage and expansive lesions of the brain parenchyma. Chest, abdominal and pelvic CT: three small hypodensis lesions of $0.4 \mathrm{~cm}$ in diameter, insufficient size for characterization, can fit very small cysts in the right liver lobe. Appropriate morphology of the spleen, kidneys, adrenal glands and pancreas. The uterus is in retroversioflexio (RVF), an extended cavity, filled with dense contents and irregular hypovascular endometrium. In the area of both ovaries that are not enlarged, there are small oval cystic lesions, probably corresponding to functional cysts. There are no free intraperitoneal fluids. In the hepatogastric ligament there are reproduced lymph nodes, the largest dimension being $1.7 \times 0.9 \mathrm{~cm}$. There are no enlarged lymph nodes in the retroperitoneum of lumbar regions, pelvis and inguinal organs. There are no enlarged lymph nodes at the base of the neck, axillary and mediastinum. Peripheral and subpleurally located nodules are located in both lungs, the largest subpleural ventral mid lobe of the right lung $0.9 \mathrm{~cm}$ in diameter, lateral in the lower lobe of the left lung $0.6 \mathrm{~cm}$ in diameter, and the lower lobe of the right lung in diameter of 0.7 $\mathrm{cm}$, which are surrounded by dairy-type areas, may correspond to secondary focal lesions. No pleural effusion.

The disease is according to FIGO and WHO scale classified as III stage, low risk and chemotherapy with methotrexate and folinic acid (MTX/ FA) is indicated. In the period from June to September 2018. patient received 8 cycles of MTX / FA chemotherapy: methotrexate $50 \mathrm{mg}$ im. Day (D)1, D3, D5, D7 and folinic acid $15 \mathrm{mg}$ po. D2, D4, D6, D8. There were no delays, difficultes or side effects during chemotherapy. hCG values during therapy: Before 1.cycle (c) of chemotherapy: 36, 013; before 2.c.: 2,717.94; before 3.c.: 183.39; before 4.c.:30.13; before 5.c.: 9.76; before 6.c.: negative; before 7. c.: negative; before 8.c.: negative.

Control diagnostic after chemotherapy: Chest, abdominal and pelvic CT (October 2018.): in the control interval in both lungs there is almost complete regression of the number and size of the previously described bilateral secondary nodules, at the site of the largest nodules are now only seen punktiform residual nodules. The rest is neat.

And at the end hCG: negative. We recommended patient contraception for at least one year and a regular, monthly hCG control. Since chemotherapy is completed 6 months ago, all the current values of hCG are normal, negative, and the control chest, abdominal and pelvic CT done in January 2019. was neat.

\section{DISCUSSION}

Gestational throphoblastic neoplasia almost always develops with or follows some form of recognized pregnancy. Most follow a hydatidiform mole but it may follow term or preterm pregnan$\mathrm{cy}$, miscarriage or tubal pregnancy $(5,6)$. Choriocarcinoma is the most aggressive GTN histological type and is characterized by early vascular invasion and disseminated disease. The clinical presentation depends on the spread of the disease and the location of the seedlings. Most common sites of metastasis are lungs. Patients diagnosed with choriocarcinoma should undergo evaluation prior to treatment to assess stage and ability to tolerate chemotherapy. The disease is staged by FIGO and WHO scoring system and the treatment is based on the total score which signifies the risk of the patient developing single-agent drug resistance. Patient with non-metastatic disease (Stage I) and low-risk metastatic (Stages II and III, score < 7) can be treated initially with single-agent chemotherapy, preferably methotrexate with cure rates approaching $80-90 \%$ (7). Women with a lowrisk disease have a good prognosis, even if tumor has spread, because treatment is usually very effective. Choriocarcinoma is characterized by high hCG values and is usually highly chemosensitive. 


\section{CONCLUSION}

Uterine choriocarcinoma is rare malignancy and is the most aggressive GTN histological type characterized by early vascular invasion and disseminated disease but it is also highly chemosensitive with high cure rates in early stage. It is important to do adequate radiological exam and to properly stage the disease prior to chemotherapy treatmen.

\section{REFERENCES}

1. Berkowitz RS, Goldstein DP, Horowitz NS. Gestational throphoblastic neoplasia: Epidemiology, clinical features, diagnosis, staging and risk stratification UpToDate. Cited 2019 Dec 16. Available from: www.uptodate.com

2. Brewer JI, Eckman TR, Dolkart RE, Torok EE, Webster A. Gestational trophoblastic disease. A comparative study of the results of therapyin patients with invasive mole and with choriocarcinoma. Am J Obstet Gynecol. 1971;109:335-40.

3. Goldstein DP, Berkowitz RS. Current management of gestational trophoblastic neoplasia. Hematol Oncol Clin North Am. 2012;26:111-31.

4. Kaji T, Ohama K. Androgenetic origin of hydatiform mole. Nature. 1977;268:633-45.

5. Cortes-Charry R, Figueira LM, Garcia-Barriola V, Gomez C, Garcia I, Santiago C. Gestational trophoblastic disease in ectopic pregnancy: A case series. J Reprod Med. 2006;51:760-3.

6. Nugent D, Hassadia A, Everard J, Hancock BW, Tidy JA. Postpartum choriocarcinoma presentation, management and survival. J Reprod Med. 2006;51:819-24.

7. Lavine TA,Alazzam M, Tidy J, Hancock BW, Osborne $R$. First line chemotherapy in low risk gestational trophoblastic neoplasia. Cochrane Database Syst Rev 2016; Jun 9;(6):CD007102. doi: 10.1002/14651858. CD007102.pub4.

Sažetak

\title{
KORIOKARCINOM MATERNICE - PRIKAZ SLUČAJA
}

\author{
V. Paradžik Pašalić, J. Lešin, V. Matković i S. Lide Škalec
}

Koriokarcinom jedan je od histoloških tipova gestacijske trofoblastične neoplazije (GTN), rijetke skupine malignoma nastale abnormalnom proliferacijom tkiva trofoblasta i predstavlja najagresivniji histološki tip GTN. Odlikuje se ranim krvožilnim bujanjem i udaljenim presadnicama. Klinička slika ovisi o proširenosti bolesti i smještaju presadnica. U ovom radu prikazan je slučaj 32 godišnje bolesnice upućene u našu ustanovu radi specifičnog liječenja koriokarcinoma maternice dijagnosticiranog u drugoj ustanovi. Bolest je prema FIGO i WHO ljestvici klasificirana u III stadij niskog rizika. Liječenje metotreksatom i folnom kiselinom dovelo je do negativizacije početno izrazito povišenog tumorskog biljega humanog korionskog gonadotropina (hCG) i potpunog povlačenja promjena opisanih CT-om.

KLJUČNE RIJEČI: gestacijska trofoblastična neoplazija, koriokarcinom, FIGO $i$ WHO klasifikacija, hCG, metotreksat 